ISSN: 2162-3104 Print/ ISSN: 2166-3750 Online

Volume 8, Issue 1 (2018), pp. 109-130

(C) Journal of International Students

http://jistudents.org/

doi: 10.5281/zenodo.1101039

\title{
Motivation, Induction, and Challenge: Examining the Initial Phase of International Students' Educational Sojourn
}

\author{
Paul Cowley \\ Denis Hyams-Ssekasi \\ University of Bolton, United Kingdom
}

\begin{abstract}
This study explores the initial higher education experiences of first-year international students in the United Kingdom. Questionnaires and semistructured interviews were carried out with 20 new international students undertaking a business degree at a U.K. university. The students described the key motivating factors for studying abroad and the fundamental issues and challenges they encountered. The language barrier, academic skills and orientation were highlighted as being integral to their development. A comprehension of international students' initial academic and social needs is important in enabling universities to develop systems that will meet the prevailing needs of these learners.
\end{abstract}

Keywords: international students, induction, student adjustment, student motivation

Statistics indicate that the growth of international students choosing to come to the United Kingdom to study is set to continue (Altbach \& Knight, 2007; Greenaway \& Tuck, 1995; Higher Education Statistics Agency, 2016; Vickers \& Bekhradnia, 2007). Key areas of research regarding this trend focus on the drivers and barriers relevant to international students. International students are motivated by a range of factors which can potentially influence their decision to come to the United Kingdom (Hyams- 
Ssekasi, Mushibwe \& Caldwell, 2014; Lee, 2014; Maringe \& Carter, 2007; Mazzoral \& Soutar, 2002). These expectations (Cowley, 2016) can be problematic if they do not correspond with the standards and prospects of the higher education institution they are seeking to study at (Kingston \& Forland, 2008; Rae \& Woodier-Harris, 2012). This suggested gap in expectations can lead to a shock for students both academically and socially.

Higher education institutions in the United Kingdom have a responsibility to their students to ensure that effective systems of support and development are in place. This support should be relevant, timely and encompass all areas of the student experience both inside and outside of the classroom (Caldwell \& Hyams-Ssekasi, 2016; Quality Assurance Agency [QAA], 2015; Spencer-Oatey, Dauber \& Williams, 2014). Key literature points to areas of best practice regarding the induction of international students; focusing on timings, integration, social and pedagogical considerations (Rae \& Woodier-Harris, 2012; QAA, 2015; Ramachandran, 2011; Ridley, 2004; Tierney, 2000). This study will seek to explore these areas of the student experience against the context of international students' expectations and needs whilst studying in the United Kingdom with a specific emphasis on their initial experiences.

\section{LITERATURE REVIEW}

The educational migration of international students is a continuing worldwide trend (Altbach \& Knight, 2007; Arambewela \& Hall, 2009; Greenaway \& Tuck, 1995; Vickers \& Bekhradnia, 2007). The United Kingdom is seen as the second most popular destination for international students after the United States (Baskerville, MacLeod \& Saunders, 2013). Reference to statistics indicates a rise in numbers over the last quarter of a century from 95,900 international students in 1992 (Greenaway \& Tuck, 1995) up to 240,390 students in 2005 (Vickers \& Bekhradnia, 2007). Recent figures show a total number of 436,880 international students (Higher Education Statistics Agency, 2016). It is anticipated that by 2025, the number of students aspiring to undertake higher education in the United Kingdom will rise further (Altbach \& Knight, 2007; Thomas \& Cornuel, 2011).

\section{Motivators}

Researchers have identified several drivers that influence international students to pursue higher education in other countries (Hyams- 
Ssekasi et al., 2014; Lee, 2014; Maringe \& Carter, 2007; Mazzoral \& Soutar, 2002). A key idea in the movement of international students is 'push-pull'. (Mazzarol \& Soutar, 2002). The 'push' can involve political, economic and social factors in a student's home country whilst the 'pull' refers to destination factors (Zajda, 2015); e.g. HEI reputation, employment opportunities, marketing practices (Brooks \& Waters, 2011; Mazzarol, 1998). According to (Hyams-Ssekasi et al., 2014), international students are drawn to study abroad because of the potential career opportunities it gives them as well as the introduction of new cultures and ideas. Although there are invaluable benefits to studying abroad; the rationale for destination choice can be complex (Mazzarol, Savery, \& Kemp, 1997) due to the economic and social status of the international students (Pimpa, 2003). In some instances, the decision of where to study can be further dictated by other issues e.g. social factors, climatic factors, cost factors, recommendations and knowledge of location (Mazzarol et al., 1997). Huang (2013) notes that students are motivated to study in the United Kingdom because they feel the experience will help them develop their employability skills and understanding of commercial issues and opportunities.

A study by Kember, Ho, and Hong (2010) suggested that international students are motivated by a range of factors: compliance, goals, lifestyle, career choice and sense of belonging. Intrinsic and extrinsic drivers have been put forward as being integral in the decision-making process for international students (Pintrich, Marx, \& Boyle, 1993; Stage \& Williams, 1990). An example of an intrinsic motivator could be the academic challenge of undertaking a course, whereas an extrinsic motivator may be the desire to achieve a reward as the result of the successful completion of a course (Byrne et al., 2012; Bista \& Foster, 2016; Dev, 1997; Donald, 1999; Lepper, 1988; Paulsen \& Gentry, 1995). The decision to pursue overseas education can also be perceived as preparation for future plans (Fang \& Wang, 2014); however, there exist social and academic gaps in what international students gain whilst studying in overseas universities (Hyams-Ssekasi et al., 2014).

\section{Induction}

U.K. HEIs place a large emphasis on ensuring that new students are properly introduced to their systems and structure (Spencer-Oatey et al., 2014). Familiarizing international students with the rules and culture of a potentially very new and strange study environment is paramount. In addition to this, newly arrived international students can potentially be 
challenged by seemingly straightforward issues: accommodation, bank arrangements, and geographical orientation (Wu, Garza, \& Guzman, 2015). These non-academic issues can impact on a student's academic development and success if they are not addressed properly. The responsibility of supporting new students ultimately lies with the relevant HEI (QAA, 2015; Spencer-Oatey et al., 2014).

Recognizing the potential for anxiety and stress experienced by international students starting a course in a new country, HEIs place a large emphasis on the induction processes as a way of effectively combatting any initial problems in the university experience of international students (Alsford \& Rose, 2014; Andrade \& Evans, 2009; Ramachandran, 2011). A positive student experience during the induction phase of the course can be potentially beneficial to both students and the institution in terms of retention and outcomes (Spencer-Oatey et al., 2014). A warning from (QAA, 2015) is that of stand-alone inductions which, happen at the start of the academic year but do not have any bearing on any other part of the student experience during the academic calendar. Induction should be a more long-term integrated aspect of the student experience (Carroll \& Ryan, 2007). These processes could be supported through additional activities e.g. one to one sessions early in the academic year between students and staff (Higher Education Academy, 2014b). Initial activities of induction and orientation could be reinforced through a meaningful mentoring system, giving the students an accessible point of reference to approach when necessary (Ramachandran, 2011).

\section{Challenges and Adjustments (Academic)}

Language barrier is perceived as one of the primary hindrances to learning for international students (Holmes, 2006; Medved, Franco, Gao, \& Yang, 2013; Turner \& George, 2011). Not just because of its practical importance in terms of understanding basic and technical language, classroom interaction, research and assessment production (Ryan \& Hellmundt, 2003; Bailey, 2010), but also because of its potential psychological impact on struggling international students (Yeh \& Inose, 2003). The nature of U.K. teaching methods and assessment is problematic and potentially disadvantageous to those students whose first language is not English (Chaudron, 1988). International students may also be troubled by a lack of confidence resulting in a hesitancy to ask questions or seek clarification in class (Medved et al., 2013). Ultimately, students are going to relate to learning materials better in their native language (Chaudron, 1988; 
Gudhlanga, 2005) and subsequently produce superior work in their first language (Otto, 1997; Siepmann, 2001). Critically, students producing work in another language potentially take longer to produce the same standard of work (Chaudron, 1988), which may be in turn detrimental to their learning experience. International students may also be troubled by a lack of confidence resulting in a hesitancy to ask questions or seek clarification in class (Medved et al., 2013).

The standard of academic writing produced by a student can be influenced by their nationality. Factors such as cultural and educational background can impact upon the interpretation and application of the information and sources they use (Lillis, 2001; Medved et al., 2013). It has been argued that because of limited language levels, international students may struggle to distinguish between credible and non-credible sources, potentially resulting in work which is poorly supported (Lahlafi \& Rushton, 2015; Turnitin, 2012; Zimerman, 2012). Equally as problematic, is the potential for limited application and synthesis in student work (MacMillan \& MacKenzie, 2012).

In an academic context, international students may underachieve as a result of less than effective teaching practice (Rastall, 2004). Another viewpoint comes from Kington and Forland (2008) who suggested that the underperformance of international students may be the result of a gap between expectations and the new teaching styles they encounter. This difference in expectation and reality (Byrne \& Flood, 2005) is further supported by Rae and Woodier-Harris (2012) who asserted that because domestic and international students may be different in their responsiveness to certain learning methods, some teaching styles and assessments may be more naturally suited to home students rather than international students (Liu, 2009). Interestingly this idea is questioned by Turner (2006) using the suggestion of Chinese students in certain literature as being less effective critical thinkers.

\section{Challenges and Adjustments (Non-Academic)}

The experience of living in a new culture can provide international students with the opportunity to develop new skills and experiences, whilst potentially receiving meaningful work experience and networking opportunities (Andrade, 2006; McClure, 2007). Making this transition to a new culture can be both difficult and shocking (McInerney \& King, 2012). International students may struggle for a range of non-academic reasons: 
financial concerns (Thomas, 2002), accommodation, travel and separation from family and friends (Rees \& Porter, 1999).

Central to the suggestion of international students experiencing culture shock is that of isolation and acculturation (Bochner, Hutnik \& Furnham, 1985; Smith \& Khawaja, 2011). Research has suggested that the social integration of students within their own national group and outside that group with students from other backgrounds and cultures (Bochner, 1982; Townsend \& Wan, 2007) can lead to higher student satisfaction which can in turn be beneficial to both the student and the institution of study (Tinto, 1975, 1998). Research into student integration has suggested that students who are socially connected to other students as well as staff and societies are more likely to successfully complete their studies (Severiens \& Wolff, 2008). Baker and Siryk (1999) identified the importance of academic adjustments (the extent to which a student can cope with the various educational demands) and social adjustments (the extent to which a student is coping with new interpersonal dynamics and relationships) as being integral to a student's wellbeing and academic success. This adaptation to the systems and cultures of university life (Rienties, Beausaert, Grohnert, \& Niemantsverdriet, 2012; Tinto, 1975), is problematic and does not necessarily fit with the typical dynamics of a university (Jochems, Snippe, Smid, \& Verweij, 1996).

The process of acculturation has been described as a number of groups coming together in a given context; typically, the larger group will change less than the other group(s) (Berry, 1999). The challenge in such situations for both the students and the institution is developing effective strategies for working together (Russell, Rosenthal, \& Thomson, 2010). In situations of acculturation, some students may withdraw from communicating with students who do not share the same language or cultural background and values (Thomas, 1983).

The issue of acculturation is an important one; which potentially, can further compound any challenges faced by international students when trying to adapt to the various teaching styles and pedagogical considerations they likely encounter in a U.K. HEI (Robertson, Line, Jones, \& Thomas, 2000; Smith \& Khawaja, 2011).

\section{RESEARCH METHOD}

The research was conducted at a U.K. university with approximately 6,000 students. The university is considered to be distinctive because of its widening participation ethos. Although the university is primarily made up 
of U.K. students, it does have a significant intake of international students. The majority of the international students at the university are Chinese with the remaining international students coming primarily from different parts of south Asia and Africa. Additionally, the university also has Erasmus partnerships, which ensure the arrival of students from a number of European countries each year. The aim of the researchers was to ensure a sample that reflected this makeup of nationalities at the university (both international and Erasmus). Ultimately, the initial sample was made up of 20 students coming from eight different countries: China, Nigeria, Pakistan, India, Bangladesh, Sri Lanka, Finland, and Germany. For all the students involved, it was their first year of study in the United Kingdom and had just recently completed their first semester. Although the research sample is small, it offers a wealth of information about the international students' needs, expectations and experiences (Bock \& Sergeant, 2002).

The research used a mixed method design (Tashakkori \& Teddlie, 2003), which involved a sequential explanatory approach (Creswell, PlanoClark, Guntmann, \& Hanson, 2003). A two-phase approach was used. The first stage involved a questionnaire (Rowley, 2014) designed to identify specific areas relevant to the research aims (motivating factors, academic and non-academic challenges, students' experiences of induction at the university). Previous research in this area (Hyams-Ssekasi et al., 2014) indicated to the researchers that these areas of feedback are potentially quite broad, providing a wide range of information. The purpose of the questionnaires in this study would be to give the researchers an opportunity to identify and follow up on the most significant initial findings (Creswell \& Plano-Clark, 2011); this follow-up would happen in the semi-structured interviews (the second stage of the sequential approach).

One of the researchers had access to the international students due to his role as an Erasmus coordinator at the university. An email was sent to all the pre-identified first-year international business students (a total of 33), asking them to participate in the research. A total of 12 students responded shortly after. A follow-up email was sent out and five extra students showed an interest in the research. It was at the later stage that additional students voluntarily asked if they could take part in the student research (Biernacki \& Waldorf, 1981).

The information from the questionnaires was analyzed by the two researchers. The more significant data provided the basis of the three themes to be addressed in the semi-structured interviews. The themes identified were (a) What motivated the students to come to a U.K. university to study? (b) What impact has induction had on the social and academic orientation of 
the students? (c) What challenges have the students experienced during their initial period of study in the United Kingdom?

Individual interviews with both researchers were conducted, recorded and transcribed. The semi-structured format (Cameron \& Price, 2009; Carruthers, 1990) was used as a data gathering tool. In total, 10 international students (see Table 1) were interviewed in order to gain a better understanding of their expectations, areas of challenge and experiences during the initial stages of their new course.

The researchers were conscious of key ethical issues (British Education Research Association, 2011) when undertaking a research project involving current students. Ethical issues were considered throughout the duration of the research. Initial contact with the potential respondents was made through a third party; at which point the research project was clearly outlined and the students were advised that any subsequent participation was entirely voluntary. The potential respondents were advised that any participation in the research project would be totally confidential (they would be referred to by pseudonyms (see Table 1) in any subsequent publication). The potential respondents were also advised that they could withdraw from the project at any time and this would have no impact on their studies at the university. The respondents were further advised of this information at several points throughout the research (BERA, 2011; Perryman \& Coughlan, 2014).

Table 1. Demographic profiles of interview respondents.

\begin{tabular}{llll}
\hline Pseudonym & Gender & Home country & \multicolumn{1}{c}{ Level } \\
\hline David & Male & China & Postgraduate \\
Neil & Male & China & Undergraduate \\
Jane & Female & Nigeria & Undergraduate \\
Jack & Male & Finland & Undergraduate \\
Louise & Female & Germany & Undergraduate \\
Nicola & Female & China & Undergraduate \\
Mark & Male & Nigeria & Postgraduate \\
Samantha & Female & China & Undergraduate \\
Albert & Male & Pakistan & Postgraduate \\
John & Male & India & Postgraduate \\
\hline
\end{tabular}




\section{RESULTS}

In this section, the findings from the questionnaires and the interviews are discussed together.

\section{What motivated the students to come to a U.K. university to study?}

When asked about the key factors for choosing the United Kingdom as a study destination. The respondents provided a range of feedback in the questionnaires: agent advice, recommendations of friends and family, work experience. The majority of the questionnaire feedback focused on the educational reputation of the United Kingdom (Baskerville, et al., 2013). Respondent feedback in the interviews suggests that the students are also motivated by other non-academic issues e.g. social drivers and family issues (Mazzarol et al., 1997):

"The main reason I have arrived in the UK to study is because a lot of my close family are here." - Mark

"As well as studying in the UK, I really want to travel around the UK as a tourist." —Jack

This potentially presents the chosen university with a challenge: how does it put appropriate and meaningful educational based systems in place for students whose primary motivation may not be education based?

Further feedback from the respondents interviewed, provided clarification of the reasons why they chose the United Kingdom to study. Focusing on 'push-pull' issues, for example, employment and education:

"I want to get a good well-paid job. A UK education gives me the best chance of doing this." - John

"I am here because there are no better places for me to study at home." -Nicola

These two responses give different perspectives of the same issue (self-development and progression as a motivator). The response of John is one which is typical of the key literature (Maringe \& Carter, 2007; HyamsSsekasi et al., 2014; Lee, 2014; Mazzoral \& Soutar, 2002) in so much he is indicating a positive interest regarding something in the destination country (in this case a good standard of education). In contrast, Nicola is being influenced by a negative domestic factor, this is something which she perceives to be missing in her home country (in this case a comparable 
education level or opportunity; Fang \& Wang, 2014; Maringe \& Carter, 2007).

Focusing on employability, some of the respondents gave more detail regarding how they expect to achieve better prospects upon graduation:

"My background is a technical one. My ambition is to become a manager in this field. I know that I lack knowledge in this area. I have chosen to do the MBA as I think it will help me give me the skills needed." -Albert

"I have come here because I want to meet like-minded people. Learn from them and also make connections with them for the future." -John

The rationale of the respondents [John and Albert] for coming to the United Kingdom was more specific and developed than the other respondents. The feedback of both John and Albert indicates a clear focus as to what they want and expect from their chosen course, focusing on employability. They have suggested that they are primarily drawn to the United Kingdom because they feel it will help provide them with the skills and connections they need to go onto the next stage of their careers. Employability as a motivator is an important consideration for HEIs in their recruitment of international students. Research (Higher Education Academy, 2014a) has suggested that HEIs have a responsibility to international students with regards to developing their employability skills. Institutional good practices include helping international students in the development of transferable skills (Meredith, 2010), specialist careers advice, networking and work experience opportunities (Huang, 2013).

\section{What impact has induction had on the social and academic orientation of the students?}

The feedback from the questionnaires indicated that their induction had been positively received by the respondents. Feedback suggested that the induction for this cohort of students had been helpful in a range of academic and non-academic areas: getting to know the staff, meeting other students, receiving practical advice regarding issues of travel, finance and accommodation. The induction for this group of students happened in September 2015, the majority of the respondents indicated that they attended the various sessions at both university and school level. The students not present in the United Kingdom at the time of induction make 
up the remaining $20 \%$. The respondents who were present at the induction provided several insights into their experiences of induction at the university:

"It was useful. Giving us advice, not just about the university rules but other important things such as accommodation, banking and travel." -Neil

The feedback of Neil hints at the potential impact of the nonacademic factors facing international students both upon on their arrival and throughout their time at university; touching on a range of important practical issues (Wu et al., 2015). Additionally, the opportunity to quickly begin mixing with other students during the induction week (Alsford \& Rose, 2014) was also welcomed:

"It was nice to meet new people and make friends. It made my arrival in the UK more comfortable."-Jane

The respondents described how useful the presence of the various social media sites used by the university had been to them; giving them both important information and also the opportunity to connect with other students at the university:

"I went to the university Facebook page before I arrived. I am glad I did, it gave me a lot of useful information; it also gave me the chance to speak with other students." - Samantha

Another aspect of the induction program highlighted in the feedback was timing. A useful example was highlighted by Louise:

"I arrived in the UK after induction. I spent quite a lot of time asking my classmates about things like Moodle access and assessments. I got it eventually but it was a little frustrating to start with."

This comment could potentially highlight a systemic gap: how meaningful are the orientation processes for late arriving students? Other issues of timings focused on resources at the university:

"The library induction was useful, but I think it was maybe a little early, we should have had that when we were more familiar with the university or about to undertake the assessments." —Jack

The feedback of the respondents is reflective of key literature regarding induction. The induction process is not only important in helping international students quickly understand important institutional 
information; e.g. library systems (Baron \& Strout-Dapaz, 2001; SpencerOatey et al., 2014) but also supporting them in broader areas outside the university (Andrade \& Evans, 2009; Ramachandran, 2011). The comment made by Jack is a reminder of the importance of timings and schedules in the various orientation processes; ensuring that the information is ongoing and integrated into appropriate times throughout the academic year (Carroll \& Ryan, 2007; QAA, 2015).

Several respondents focused on language support at the university (Maringe \& Jenkins, 2015; Rae \&Woodier-Harris, 2012). Respondents pointed to their initial interactions with the university when addressing this issue:

"The pre-sessional staff are very helpful in letting you know what your level of English is and what is expected of you when you get to the university." - Louise

Respondents further indicated that the initial positive contact with students has been reinforced by ongoing support from approachable tutors and staff upon their arrival and commencement of studies (Rae \& WoodierHarris, 2012; Ramachandran, 2011).

\section{What challenges have the students experienced during their initial period of study in the United Kingdom?}

Students touched on a number of issues of adjustment and challenge in the questionnaires. Amongst the key academic issues were group work, presentations, finding suitable support texts and new teaching styles. The most frequently referenced adjustment areas highlighted in the questionnaires were writing skills and language. As indicated in the literature, the ability to write an academic assessment in a second language can be potentially problematic for international students (Chaudron, 1988; Lillis, 2001; MacMillan \& MacKenszie, 2012; Lahlafi \& Rushton, 2015). This issue was expanded on in the interviews:

"The biggest problem is understanding language and then expressing it appropriately in the assessments. " - Louise

This statement hints at the multifaceted nature of language as a problem. This student has indicated that not only does it present them with comprehension problems but also writing issues. Writing as a barrier (Lillis, 2001 ) is also a potentially complex issue; overlapping with other barriers, for example, language, academic and cultural: 
"The writing style is difficult in the UK because you have to use references." -David

"Your writing has to be your own." -Mark

While academic writing and referencing is a normal but important aspect of academic study in the United Kingdom. International students can potentially find the writing style and rules involved quite strange (Bailey, 2010). An additional layer of language related difficulty and anxiety is that of technical language (Ryan \& Hellmundt, 2003):

"You have to use professional words all the time. This was not a surprise as I had been told about this by friends, but it was still difficult." —Jack

The feedback highlights the depth of the problem that language presents to international students. Not only are students challenged by talking, writing and listening in a second language but also have to contend with terminology and subject-specific technical language (Bailey, 2010; Ryan \& Hellmundt, 2003). Such issues perhaps becoming especially acute when undertaking assessments. This was highlighted in the interviews:

"Answering exam questions was very difficult, so much detail is needed." - Louise

The respondents generally felt that the writing of assessments in the United Kingdom was difficult primarily because it was different from what they had previously done in their home countries. They felt that this issue was essentially an academic adjustment they needed to make which had come about as a result of a gap in expectations and understanding of U.K. education (Rae \& Woodier-Harris, 2012). Interestingly, although some students knew or understood that the writing style in U.K. higher education was going to be different; they didn't really appreciate how different until they were undertaking their initial assessments (Chaudron, 1988; Lillis, 2001; MacMillan \& MacKenzie, 2012; Lahlafi \& Rushton, 2015).

Class size was another immediate influence in staying connected in the classroom environment as noted in the interviews:

"I was told before I came here that the seminars are more interactive." - Jane

The feedback from Jane was supported by other respondents who highlighted the idea of frequent and positive student-staff interaction as a dynamic they expected or sensed from their initial discussions with marketing and academic staff at the university. Other students hinted at this 
being a pleasant surprise, which they have found important in building a positive and confident impression of the institution (Severians \& Wolff, 2008). Some students expressed some mild nervousness regarding the smaller and more interactive classroom dynamics:

"You are put into different groups and have to work with different people from different parts of the world." -Mark

The issues of possible shyness and apprehension could be heightened through the potentially new teaching strategies faced by the students (Rae \& Woodier-Harris, 2012):

"The teacher makes us do presentations in class, in front of strangers. This can make me nervous. I have never done anything like that before." -David

This nervousness may be a result of apprehensions that stem from the acculturated environment (Berry, 1999) some of the respondents hinted at:

"I haven't worked with anyone here other than my group of friends from China." -Nicola

When asked about the non-academic challenges they had faced; the respondents' feedback from the questionnaires focused on accommodation, finance and travel. The interview feedback in this area pointed to feelings of isolation and homesickness as being the primary non-academic issues:

"I really miss my family." - Samantha

The feedback of Samantha highlights an important issue in the education of international students. Isolation and homesickness can be problematic on two levels. Firstly, is the obvious impact of these issues on student wellbeing. Secondly, is the potential for students to be distracted by these feelings, sidetracking them from their studies:

"I initially found it difficult to settle in the UK." - Neil

"Everything just seemed really strange for around six weeks." Albert

Feedback relating to social adjustment focused on social and student support departments; in particular student services and the student union (Hart \& Rush, 2007). These departments are seen as an important way of promoting a positive student experience (Coates, 2005; Krause, 2007; Zhao $\&$ Kuh, 2004) and ultimately student success (which is obviously beneficial to both the student and the institution; Severians \& Wolff, 2008): 
"I know about the international society and know they run different activities. If there is an international society with an enterprise focus I think I would be involved in that. I am passionate about this area and is actually one of the reasons I chose the UK to study." Albert

"The school has arranged several business events; these have been very interesting." - Louise

The respondent's feedback suggested that 'outside of the classroom interactions' (Coates, 2005; Krause, 2007; Zhao \& Kuh, 2004) are seen as being potentially beneficial and important to them. Interestingly, Albert indicates that not only does he see such activities as important in helping him adjust to the university, but is one of the important motivating factors in him choosing to come to the United Kingdom to study.

\section{CONCLUSIONS}

The research notes that international students are driven to come to the United Kingdom for a variety of reasons: educational reputation, limited home country opportunity, social factors, family factors (Pimpa, 2003) and marketing influences (Brook \& Waters, 2011; Hyams-Ssekasi et al., 2014; Mazzarol et al., 1997; Pimpa, 2003). Career development was identified as a key driver with some respondents highlighting the development of their employability as being something they expect from their time in U.K. higher education. The findings indicate that the students are also motivated by networking opportunities and extra-curricular activities e.g. academic societies (Krause, 2007; Zhao \& Kuh, 2004).

Induction processes are important in ensuring the positive arrival and transition of international students. The induction processes help newly arriving international students by giving them a clear understanding of the systems and expectations at the university. International students are potentially dependent on the induction week to receive information relevant for key non-academic issues. Late arrival can be challenging for an international student; impacting on their level of understanding, confidence and interaction in the first semester.

The study indicates that international students are challenged by a wide range of academic issues. The key challenge being language. Although it is not the only barrier to learning for international students; the respondents' feedback suggested that language is especially troublesome to them because it overlaps with other areas of challenge, for example, 
understanding assessments, communication, technical language and academic writing. The research suggested that the academic challenges faced by students were typically addressed in the context of an acculturated study environment. The study notes that this mixed environment can be a potential cause of anxiety for some students. A useful thread of feedback to emerge from the research, related to the positive impact of the enrichment activities at the university as a means of not only enhancing the academic experiences of the students; for example, employability, but also as an opportunity for international students to meet and build friendships with other students (both home and international) at the university.

International students are potentially challenged by a number of non-academic issues, for example, finance, homesickness and feelings of isolation. From an academic point of view, these non-academic issues are potentially very serious in their ability to impact on a student's confidence and concentration causing them to become withdrawn or sidetracked from their studies.

\section{REFERENCES}

Alsford, S., \& Rose, C. (2014). Practice and policy to enhance student induction and transition: a case study of institution-wide change. Perspectives: Policy and Practice in Higher Education, 18(2), 51-61.

Altbach, P. G., \& Knight, J. (2007). The internationalization of higher education: Motivations and realities. Journal of Studies in International Education, 11(3-4), 290-305.

Andrade, M. S. (2006). International students in English-speaking universities adjustment factors. Journal of Research in International Education, 5(2), 131-154.

Andrade, M., \& Evans, N. (2009). International students: Strengthening a critical resource. Lanham, MD: R\&L Education.

Arambewela, R., \& Hall, J. (2009). An empirical model of international student satisfaction. Asia Pacific Journal of Marketing and Logistics, 21(4), 555569.

Bailey, S. (2010). Academic writing for international students of business. New York, NY: Routledge.

Baker, R. W., \& Siryk, B. (1999). SACQ: Student adaptation to college questionnaire: Manual. Torrance, CA: Western Psychological Services.

Baron, S., \& Strout-Dapaz, A. (2001). Communicating with and empowering international students with a library skills set. Reference Services Review, 29(4), 314-326.

Baskerville, S., MacLeod, F., \& Saunders, N. (2013). A guide to UK higher education and partnerships for overseas universities. London: UK Education International and Europe Unit. 
Berry, J. W. (1999). Intercultural relations in plural societies. Canadian Psychology/Psychologie Canadienne, 40(1), 12.

Biernacki, P., \& Waldorf, D. (1981). Snowball sampling: Problems and techniques of chain referral sampling. Sociological Methods \& Research, 10(2), 141163.

Bista, K., \& Foster, C. (2016). Exploring the social and academic experiences of international students in higher education institutions. Hershey, PA: IGI Global.

Bochner, S. (1982). The social psychology of cross-cultural relations. Cultures in Contact: Studies in Cross-Cultural Interaction, 1, 5-44.

Bochner, S., Hutnik, N., \& Furnham, A. (1985). The friendship patterns of overseas and host students in an Oxford student residence. The Journal of Social Psychology, 125(6), 689-694.

Bock, T., \& Sergeant, J. (2002). Small sample market research. International Journal of Market Research, 44(2), 235.

British Education Research Agency (BERA). (2011) Ethical guidelines for educational research. Retrieved from http://www.bera.ac.uk/wp-content/ uploads/2014/

02/BERA-EthicalGuidelines-2011.pdf.

Brooks, R., \& Waters, J. (2011). Student mobilities, migration and the internationalization of higher education. Basingstoke, UK: Palgrave Macmillan.

Byrne, M., \& Flood, B. (2005). A study of accounting students' motives, expectations and preparedness for higher education. Journal of Further and Higher Education, 29(2), 111-124.

Byrne, M., Flood, B., Hassall, T., Joyce, J., Montaño, J. L. A., González, J. M. G., \& Tourna-Germanou, E. (2012, June). Motivations, expectations and preparedness for higher education: A study of accounting students in Ireland, the UK, Spain and Greece. Accounting Forum, 36(2), 134-144.

Caldwell, E. F., \& Hyams-Ssekasi, D. (2016). Leaving home: the challenges of Black-African international students prior to studying overseas. Journal of International Students, 6(2), 588.

Cameron, S., \& Price, D. (2009). Business research methods: A practical approach. London: Chartered Institute of Personnel and Development.

Carroll, J., \& Ryan, J. (2007). Teaching international students: Improving learning for all. New York: Routledge.

Carruthers, J. (1990). A rationale for the use of semi-structured interviews. Journal of Educational Administration, 28(1). doi: 10.1108/09578239010006046

Chaudron, C. (1988). Second language classrooms. Cambridge: Cambridge University Press.

Coates, H. (2005). The value of student engagement for higher education quality assurance. Quality in Higher Education, 11(1), 25-36.

Committee of Vice Chancellors and Principals. (1995). Economic impact of international students in UK higher education. London: Author. 
Cowley, P. (2016). Managing expectations: an exploration of the issues, challenges and support systems relevant to international students in UK higher education. ICERI2016 Proceedings, pp. 2331-2340. IATED.

Creswell, J. W., \& Plano Clark, V. L. (2011). Designing and conducting mixed methods research (2nd ed.). Thousand Oaks, CA: Sage.

Creswell, J. W., Plano Clark, V. L., Gutmann, M. L., \& Hanson, W. E. (2003). Advanced mixed methods research designs. In A. Tashakkori \& C. Teddlie (Eds.), Handbook of mixed methods in social and behavioral research (pp. 209-240). Thousand Oaks, CA: Sage.

Dev, P. C. (1997). Intrinsic Motivation and Academic Achievement What Does Their Relationship Imply for the Classroom Teacher? Remedial and Special Education, 18(1), 12-19.

Donald, J. G. (1999). Motivation for higher- order learning. New directions for teaching and learning, 1999(78), 27-35.

Fang, W., \& Wang, S. (2014). Chinese students' choice of transnational higher education in a globalized higher education market A case study of W university. Journal of Studies in International Education, 18(5), 475-494.

Gudhlanga, E.S. (2005). Promoting the use and teaching of African languages in Zimbabwe, Zimbabwe Journal of Educational Research, 17(1), 54-68.

Hart, M., \& Rush, D. (2007). E-Learning and the development of "voice" in business studies education. International Journal of Educational Management, 21(1), 68-77.

Higher Education Academy (HEA). (2014a). Employability and next steps. https://www.heacademy.ac.uk/system/files/.../employability_and_next_ste ps.pdf

Higher Education Academy (HEA). (2014b). International student lifecycle. Retrieved from https:/www.heacademy.ac.uk/knowledgehub/international-student-lifecycle-0

Higher Education Statistics Agency (HESA). (2016). More student statistics. Retrieved from https://www.hesa.ac.uk/data-and-analysis

Holmes, P. (2006). Problematising intercultural communication competence in the pluricultural classroom: Chinese students in a New Zealand university. Language and intercultural communication, 6(1), 18-34.

Huang, R. (2013). International experience and graduate employability: Perceptions of Chinese international students in the UK. Journal of Hospitality, Leisure, Sport \& Tourism Education, 13, 87-96.

Hyams-Ssekasi, D., Mushibwe, C. P., \& Caldwell, E. F. (2014). International Education in the United Kingdom. Sage Open, 4(4), 2158244014562386.

Jochems, W., Snippe, J., Smid, H. J., \& Verweij, A. (1996). The academic progress of foreign students: study achievement and study behaviour. Higher Education, 31(3), 325-340.

Kember, D., Ho, A., \& Hong, C. (2010). Initial motivational orientation of students enrolling in undergraduate degrees. Studies in Higher Education, 35(3), 263-276. 
Kingston, E., \& Forland, H. (2008). Bridging the gap in expectations between international students and academic staff. Journal of Studies in International Education, 12(2), 204-221.

Krause, K. (2007). Beyond classroom walls: Students' out-of-class activities and implications for teaching and learning. Nagoya Journal of Higher Education 7(3), 301-318.

Lahlafi, A., \& Rushton, D. (2015). Engaging international students in academic and information literacy. New Library World, 116(5/6), 277-288.

Lee, C. F. (2014). An investigation of factors determining the study abroad destination choice: A case study of Taiwan. Journal of Studies in International Education, 18(4), 362-381.

Lepper, M. R. (1988). Motivational considerations in the study of instruction. Cognition and Instruction, 5(4), 289-309.

Lillis, T. (2001). Student writing access, regulation, desire. New York: Routledge.

Liu, J. (2009). From learner passive to learner active? The case of Chinese postgraduate students studying marketing in the UK. International Journal of Management Education, 7(2), 33--40.

MacMillan, M., \& MacKenzie, A. (2012). Strategies for integrating information literacy and academic literacy: Helping undergraduate students make the most of scholarly articles. Library Management, 33(8/9), 525-535.

Maringe, F., \& Carter, S. (2007). International students' motivations for studying in UK HE: Insights into the choice and decision making of African students. International Journal of Educational Management, 21(6), 459-475.

Maringe, F., \& Jenkins, J. (2015). Stigma, tensions and apprehension: The academic writing experience of international students. International Journal of Educational Management, 29(5), 609-626.

Mazzarol, T. (1998). Critical success factors for international education marketing. International Journal of Educational Management, 12(4), 163-175.

Mazzarol, T., \& Soutar, G. N. (2002). "Push-pull" factors influencing international student destination choice. International Journal of Educational Management, 16(2), 82-90.

Mazzarol, T., Savery, L. K., \& Kemp, S. (Eds.). (1997). International students who choose not to study in Australia: An examination of Taiwan and Indonesia. Canberra: Australian International Education Foundation.

McClure, J. W. (2007). International graduates' cross-cultural adjustment: Experiences, coping strategies, and suggested programmatic responses. Teaching in Higher Education, 12(2), 199-217.

McInerney, D. M., \& King, R. B. (2012). Studying “A thousand miles away": The motivational implications of cross-cultural transitions. Transitions Across Schools and Cultures (Vol. 17, pp. 205-240). Bingley, UK: Emerald Group.

Medved, D., Franco, A., Gao, X., \& Yang, F. (2013). Challenges in teaching international students: Group separation, language barriers and culture differences. Lund, Sweden: Lund University. 
Meredith, C. (2010). Teaching reflective skills and PDP to international students: How effective is the use of PebblePad? Brookes eJournal of Learning and Teaching, 2(5).

Otto, D. (1997). First language maintenance in a second language context. Presented at the Regional Conference on Early Childhood Education in Higher Education. Kadoma, Zimbabwe.

Paulsen, M. B., \& Gentry, J. A. (1995). Motivation, learning strategies, and academic performance: A study of the college finance classroom. Financial Practice and Education, 5(1), 78-89.

Perryman, L. A., \& Coughlan, T. (2014). A murky business: the ethics of conducting educational research in Facebook groups. In A. M. Teixeira \&

A. Szücs, (Eds.) Challenges for Research into Open \& Distance Learning: Doing Things Better-Doing Better Things (pp. 277-289). Oxford, UK: EDEN.

Pimpa, N. (2003). The influence of peers and student recruitment agencies on Thai students' choices of international education. Journal of Studies in International Education, 7(2), 178-192.

Pintrich, P. R., Marx, R. W., \& Boyle, R. A. (1993). Beyond cold conceptual change: The role of motivational beliefs and classroom contextual factors in the process of conceptual change. Review of Educational research, 63(2), 167-199.

Quality Assurance Agency (QAA). (2015). Supporting and enhancing the experience of international students in the UK. http://www.qaa. ac.uk/en/Publications/Documents/International-Students-Guide-15.pdf

Rae, D. \& Woodier-Harris, N. (2012). International entrepreneurship education, Education + Training, 54(8/9), 639-656.

Ramachandran, N. T. (2011). Enhancing international students' experiences: An imperative agenda for universities in the UK. Journal of Research in International Education, 10(2), 201-220.

Rastall, P. (2004). The Chinese learner in higher education: Transition and quality issues. Responding to the Needs of Chinese Learners in Higher Education, University of Portsmouth, Portsmouth, UK.

Rees, W. D., \& Porter, C. (1999). The training implications of the Government White Paper Fairness at Work. Industrial and Commercial Training, 31(1), 4-8.

Ridley, D. (2004). Puzzling experiences in higher education: critical moments for conversation. Studies in Higher Education, 29(1), 91-107.

Rienties, B., Beausaert, S., Grohnert, T., Niemantsverdriet, S., \& Kommers, P. (2012). Understanding academic performance of international students: The role of ethnicity, academic and social integration. Higher education, 63(6), 685-700.

Robertson, M., Line, M., Jones, S., \& Thomas, S. (2000). International students, learning environments and perceptions: A case study using the Delphi technique. Higher Education Research and Development, 19(1), 89-102. 
Rowley, J. (2014). Designing and using research questionnaires. Management Research Review, 37(3), 308-330.

Russell, J., Rosenthal, D., \& Thomson, G. (2010). The international student experience: Three styles of adaptation. Higher Education, 60(2), 235-249.

Ryan, J., \& Hellmundt, S. (2003, October). Excellence through diversity: Internationalisation of curriculum and pedagogy. Presented at the 17th IDP Australian International Education Conference, Melbourne, Australia.

Severiens, S., \& Wolff, R. (2008). A comparison of ethnic minority and majority students: Social and academic integration, and quality of learning. Studies in Higher Education, 33(3), 253-266.

Siepmann, D. (2001). Multi- Word discourse markers in translation: A corpus-based investigation into restrictors. Lebende Sprachen, 46(3), 97-107.

Smith, R. A., \& Khawaja, N. G. (2011). A review of the acculturation experiences of international students. International Journal of Intercultural Relations, 35(6), 699-713.

Spencer-Oatey, H., Dauber, D., \& Williams, S. (2014). Promoting integration on campus: principles, practice and issues for further exploration. Coventry, UK: University of Warwick.

Stage, F. K., \& Williams, P. D. (1990). Students' motivation and changes in motivation during the first year of college. Journal of College Student Development, 31(6), 516-522.

Tashakkori, A., \& Teddlie, C. (2003). Handbook of mixed methods in the social and behavioral sciences. Thousand Oaks, CA: Sage.

Thomas, H., \& Cornuel, E. (2011). Business school futures: Evaluation and perspectives. Journal of Management Development, 30(5), 444-450.

Thomas, J. (1983). Cross-cultural pragmatic failure. Applied Linguistics, 4(2), 91112.

Thomas, L. (2002). Student retention in higher education: the role of institutional habitus. Journal of Education Policy, 17(4), 423-442.

Tierney, W. G. (2000). Power, identity, and the dilemma of college student departure. In J. M. Braxton (Ed.), Reworking the student departure puzzle (pp. 213-234). Nashville, TN: Vanderbilt University Press.

Tinto, V. (1975). Dropout from higher education: A theoretical synthesis of recent research. Review of Educational Research, 45(1), 89-125.

Tinto, V. (1998). Colleges as communities: Taking research on student persistence seriously. The Review of Higher Education, 21(2), 167-177.

Townsend, P., \& Wan, C. (2007). The impact of multicultural experience in the development of socio-cultural adaptation for international business students. International Journal of Educational Management, 21(3), 194212.

Turner, K., \& George, M. (2011, March). Hybrid teaching and learning in contemporary English teacher education. In M. Koehler \& P. Mishra (Eds.), Proceedings of the Society for Information Technology \& Teacher 
Education International Conference (pp. 796-801). Chesapeake, VA: Advancement of Computing in Education.

Turnitin. (2012). The white paper: The sources in student writing. Retrieved from http://turnitin.com/assets/en_us/media/sources_in_writing_he_2012.php

Vickers, P., \& Bekhradnia, B. (2007). The economic costs and benefits of international students. Oxford: Higher Education Policy Institute.

Wu, H. P., Garza, E., \& Guzman, N. (2015). International student's challenge and adjustment to college. Education Research International, 2015, 202753.

Yeh, C. J., \& Inose, M. (2003). International students' reported English fluency, social support satisfaction, and social connectedness as predictors of acculturative stress. Counselling Psychology Quarterly, 16(1), 15-28.

Zajda, J. (2015). Second international handbook on globalisation, education and policy research. New York: Springer.

Zhao, C. M., \& Kuh, G. D. (2004). Adding value: Learning communities and student engagement. Research in Higher Education, 45(2), 115-138.

Zimerman, M. (2012). Plagiarism and international students in academic libraries. New Library World, 113(5/6), 290-299.

PAUL COWLEY is a Lecturer in Business Management at the University of Bolton, United Kingdom. His research interests include organisational behaviour, education management, acculturation, and business pedagogy for international students. Email: p.cowley@bolton.ac.uk

DENIS HYAMS-SSEKASI, EdD, is a Lecturer in Business Management at the University of Bolton, United Kingdom. His research interests include the transitional experiences of international students in higher education, as well as intercultural communication and social impacts. Email: d.hyamsssekasi@bolton.ac.uk 